\title{
CONCEPTUAL MISUNDERSTANDINGS IN THE STRUCTURATION OF ANTI-CRISIS ECONOMIC POLICY: LESSONS FROM THE GREEK CASE
}

\section{Charis Vlados ${ }^{1}$, Nikos Deniozos ${ }^{2}$, Demosthenes Chatzinikolaou ${ }^{3}$, Michail Demertzis ${ }^{4}$}

\footnotetext{
${ }^{1}$ Department of Economics, Democritus University of Thrace, Greece School of Business, University of Nicosia, Cyprus

2 - Department of Turkish Studies and Modern Asian Studies, National and Kapodistrian University of Greece; - Department of Economics, Democritus University of Thrace

${ }^{3}$ Democritus University of Thrace

${ }^{4}$ Department of Political Science and History Panteion Unversity, - Department of Balkan Studies (Econmy and Politic) University of Macedonia
}

1vad.coop@gmail.com; ${ }^{2}$ deniozos@gmail.com;

3idimos. Chatzinikolaou@gmail.com; ${ }^{4}$ michael de 13@yahoo.com

DOI: https://doi.org/10.18196/jgpp.53100

Article Info

Article history:

Received 20 Sep 2018

Revised 22 Nov 2018

Accepted 30 Nov 2018

\section{Keywords:}

Economic policy, Normative versus positivistic economics, Economic policy strategy, Structural versus conjunctural economic policy, Greek crisis

\begin{abstract}
The objective of this study is to clarify the prevailing vague and sometimes misguided understanding regarding the articulation of economic policy, especially in the context of socioeconomic systems in structural crisis. The distortions of the economic policy are keep reproducing and spreading usually because of three disorientating conceptual sources: a) the view of economic policy supposedly as a de-ideologized construction, or as a de-technicalized voluntarism, b) the view of economic policy supposedly as a de-strategized synthesis, c) the view of economic policy as a supposedly automatic, ungradated and timeless procedure.For a socioeconomic system to exit from its crisis and by applying these concepts to the Greek case, we see as a prerequisite the interruption of this vicious circle of misconceptions, towards the trajectory of a virtuous circle of valid understanding the meaning of economic policy.
\end{abstract}

\section{INTRODUCTION}

All the individual phenomena of the crisis that marked the last decade, the stock market shocks of 2008, the governmental bailouts of big financial organizations, the recovery of some national GDP growth rates, the persistent and constant high rates of unemployment within a lot of national economies, they all seem to lead nowadays to an emerging, global status quo of a 'new globalization' (Adda, 2006; Aglietta, 2010; Boyer, 2015; 
281 Chavagneux, 2016; Cohen, 2004; Greenspan, 2008; Grove, 1999; Kotler \& Caslione, 2009; Laudicina \& Peterson, 2016; Naisbitt, 2006; Naisbitt \& Naisbitt, 2010; National Intelligence Council (U.S.), 2008; Rodrik, 2011; Sapir, 2011; Vlados, Deniozos, \& Chatzinikolaou, 2018b, 2018a; B $\lambda$ ádos, 2006, 2017).

Under these difficult circumstances, the Greek crisis seems far from over and it is apparently moving towards a long-term state of societal and economic entrapment to feeble growth rates (International Monetary Fund. European Dept., 2017).

On a deeper level of analysis, we think that one of the reasons for the painful conservation of the Greek crisis is also the existence/reproduction of some misconceptions on what an effective anti-crisis economic policy means; and these misconceptions do not cease to influence greatly the shaping of the public opinion and the public discourse among a great part of the Greek political elites

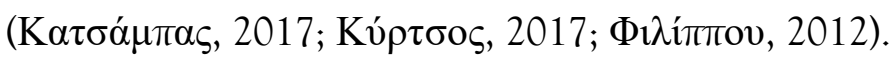

\section{The current dynamics of the restructuring of globalization}

Because of the emerging discipline of the globalization's restructuring crisis there is now a new, pivotal theoretical field that reinvigorates all social sciences. In particular, the notion of crisis seems progressively as a new conceptual boundary of methodological reposition of all social sciences and inside a globalized perspective; and this change is simultaneously and cross-disciplinary reflected, from modern political science and geopolitics (Ancel, 1936; Carroué, 2007; Chauprade, 2007; Huntington, 2017; Lacoste, 2006, 2014; 
Lévy, 2008; Luttwak, 1990; Strange, 1996), to the new 'thematic branches' of economics (Acemoglu, Johnson, \& Robinson, 2004, 2000; Acemoglu \& Robinson, 2009, 2012; Amable, 2005; Berger \& Dore, 1996; Chang, 2006; Crouch, 2005; D. North, 2005; O. E. Williamson, 2000) and from sociology (Abélès, 2008; Beaujard, Berger, \& Norel, 2009; Carroll, 2010; Colic-Peisker, 2010; Dufoix, 2011; Giddens, 1990; Heilbron, Guilhot, \& Jeanpierre, 2009; Keck, 2010; King \& Le Galès, 2011; Martel, 2010; Moore, 1966; Robertson, 1992) and social psychology to cultural studies (Cuche, 2013; Gorz, 2003; Hannerz, 1992; Koch \& Mattelart, 2016; Mattelart, 2009; Mattelart \& Neveu, 2010; Noiriel, 2007) ${ }^{1}$.

This synthesis of these new approaches shows us that, progressively, the global restructuration we are going through can be examined as the byproduct of the long process (of approximately 30 years) of the structural maturation of globalization. After all, as in every phase of the evolution of global capitalism (Michalet, 1985; Salmon, 2000; St-Onge, 2000; Veltz, 2008), the current one regarding the crisis was born as a result of a structural destabilization of the old model of development, on a global scale - a destabilization that drastically unfolded the last few years, since 2008. This took place through the long chain of events set off by the collapse of the

\footnotetext{
${ }^{1}$ Because, apparently, without a valid understanding of the all-inclusive/evercompeting global dynamics and crisis, any interpretative attempt of the particular contemporary socioeconomic phenomena, regardless of the analytical level, can be nothing but insufficient.
} 
286 subprime mortgage loans and spread out everywhere, on all levels of our socioeconomic coexistence, on a global scale. Of course, this chain did not occur out of nowhere: On the contrary, the crisis first took shape on the structural maturation of the previous developmental model of globalization (Amsden, 2001; Bairoch, SaintGirons, \& Asselain, 2005; Krugman, 1992; North, 1990; Perroux, 1962; Ray, 1998); a structural maturation that has been taking place for the last three decades, from the mid-80s to approximately the middle of the 2000s.

So, what we call a crisis of globalization (Abraham-Frois, 2002; Aglietta, 1997; Boyer, 1986; Chevalier \& Pastré, 2002; Dockès \& Rosier, 1983, 2002; Kleinknecht, 1986; Lorenzi, Pastré, \& Toledano, 1980; Mandel, 1995; Perez, 2010; Rosier, 1985; Schumpeter, 1939) has quite naturally overturned almost everything that we used to take as granted, on every level, both nationally and internationally.

And especially today, the structural overcoming of the crisis and the restructuring of the global system seem to require, as an absolutely necessary condition, the structuration of economic policies that belong to a new logic, in order for our world to enter the path of a new, steady model of global development (Aghion, Algan, Cahuc, \& Shleifer, 2009; Alesina, Favero, \& Giavazzi, 2012; Balcerowicz, 1994; Baum, Checherita-Westphal, \& Rother, 2013; Buti, Turrini, \& Noord, 2014; Eichengreen \& Panizza, 2014).

And this realization, in fact, acquires an even greater meaning in the cases of countries with a vulnerable socio-economic structure, 
especially under internal crisis conditions, like the case of Greece nowadays.

\section{The main interpretative approaches to the Greek crisis}

The Greek crisis was expressed and is still reproduced, while continuously being transformed, within an ever-intensifying competitive framework and uncertainty that characterizes the current global restructuring. Its analysis and interpretation has been attempted by many scholars the last few years. Most of these analyses focus on the conditions of the individual internal causes of the crisis and also on the external conditions of its co-evolution, in the changing context of the global environment (Boufounou \& Avdi, 2016; Chalikias, 2017; Cholezas, Kanellopoulos, Mitrakos, \& Tsakloglou, 2013; Georgievski \& Mostert, 2016; Giannitsis \& Zografakis, 2015; Haliassos, 2015; Kapitsinis, 2018; Kentikelenis, 2018; Manasse, 2015; Matsaganis, 2013; Mitsakis, 2014; Mitsopoulos \& Pelagidis, 2009; Petmesidou \& Polyzoidis, 2015; Pitelis, 2012). In these approaches there is indeed a great variety of overlapping interpretative factors and dimensions regarding the Greek crisis.

More specifically, a great part of these analyses projects mainly the financial dimension, regarding basically the Greek crisis as a byproduct of the 2007-2009 international financial crisis. Under these circumstances, the usual conclusion is that the steep rise of the national debt and the unsustainable size of the government deficit are the crisis' epicenter and main source (Christodoulakis, 2010; Kuforiji, 2016). 
Some regard the particularly weak 'regional' position of the Greek economy within the global system as the interpretative center and, accordingly, they observe the Greek crisis as one of the 'symptoms' of the struggling peripheral economies of Europe (Kazemi \& Sohrabji, 2012; Magoulios \& Chouliaras, 2014; Marangos, 2017; Mavroudeas, 2014; Mavroudeas, 2016). Some others, with a similar reasoning, highlight the poor political management of successive Greek governments with their lenders (Hardouvelis \& Gkionis, 2016; Zettelmeyer, Trebesch, \& Gulati, 2013).

In other approaches, it is the structural inadequacies of the Greek economic system both in terms of 'supply' and in terms of 'demand' - including the particularly sizable black economy and tax evasion - that hold the interpretative primacy (Andreou, Andrikopoulos, \& Nastopoulos, 2017; Bitzenis, Vlachos, \& Schneider, 2016; Ioannides \& Pissarides, 2015; Triantopoulos \& Staikouras, 2017).

There are also those that are focused on the overall problematic structure of the politico-economic environment, which, after having hatched the crisis, was proven to be incapable of dealing with it, mainly due to the preservation and the systematic reproduction of clientelism within the Greek public sector (Christopoulou \& Monastiriotis, 2016; Gkintidis, 2018; Juko, 2010; Koniordos, 2011; Rapanos \& Kaplanoglou, 2014). Some scholars, in turn, regard this overall socio-political inadequacy as the cause for the constant resistance against the proposed reforms (Skalkos, 2018). 
All together, the above approaches cover, in a complementary manner, the examination and interpretation of the Greek crisis satisfyingly enough. However, one can detect, in a relatively big part of them, an inadequacy of deepening their reason towards the structural and evolutionary dimension of this crisis (Vlados, Deniozos, Chatzinikolaou, \& Demertzis, 2018) as well as to the examination of the existence and perpetuation of certain conceptual misunderstandings, in relation specifically to the endogenous restrictions on the structuration of an effective anti-crisis economic policy.

In this paper we focus on this last dimension and specifically on the combined reproduction and spread of three kinds of conceptual distortion, regarding the structuration of an anti-crisis economic policy. In particular:

- The economic policy either as, supposedly, a deideologized construction or a de-technicalized voluntarism

- The economic policy as, supposedly, a de-strategized synthesis

- The economic policy as, supposedly, an automatic, ungradated, and instant and without 'friction' process.

It is on this matter we consider it useful to attempt some, essential in our perspective, critical conceptual clarifications. 
THE PROBLEM OF THE STRUCTURATION OF A MODERN ECONOMIC POLICY IN CONDITIONS OF CRISIS

According to the classic definition by J. Tinbergen, economic policy is the deliberate control of a number of instruments, with the purpose of achieving a certain number of targets (Tinbergen, 1956). Also, by following the classic line of thought of E.S. Kirschen (Kirschen, 1964), economic policy is the economic view on the general governmental policy, i.e., the intentional intervention of the state in the economic affairs, in order for it to accomplish each time certain goals. So, first and basic dimension of the analysis of economic policy must always be the clarification and the understanding of its specific intentions - its aims. Without clear aims there cannot be, ever, real economic policy.

It is, however, exactly on the issue of the planning and the implementation of the aims of economic policy that the following crucial matters emerge; matters that seem to have been relatively neglected on an interpretative level regarding the negotiation of the Greek crisis particularly, but not exclusively.

The ideological-technical constituents of the structuration of modern economic policy

Overall, economic policy is composed always by decisions (of intervention or deliberate abstention from intervention) of the state and the organizations depending on it, which have as a main purpose the regulation of the conditions of production, distribution or use of the resources, as Boissieu specifies (Boissieu, 1980). Accordingly, 
there are always certain questions arising before the structuration of any kind of economic policy:

- What is the specific economic problem to deal with? A question that sets the basis for the formulation of the policy framework of objectives and targets.

-Why is this actually a problem? A question that determines the political expediency of dealing with it.

- Which are the most important causes of the problem? A question that sets the boundaries of its theoretical examination.

- What is socially desirable and achievable? A question that formulates the content of the means and measures of the economic policy.

Nevertheless, many analyses on the Greek crisis, academic or not, seem to have the wrong impression that the structuration of an effective economic policy is just a 'technical' matter. In other words, they express the belief - usually in an indirect way - that there can be always 'only one right solution' against the crisis, regardless of the political environment, the social priorities and any ideological parameters (Åslund, 2011; Buiter \& Rahbari, 2011; Carfi \& Schiliro, 2012; European Commission, 2010; Featherstone, 2011; Glynos \& Voutyras, 2016; Hughes, 2011; Katsimi \& Moutos, 2010; Kouretas \& Vlamis, 2010; Koutsoukis \& Roukanas, 2011; Mourmouras, Ivvanova, Anayotos, \& Mayer, 2003; Terzi, 2015; Tsoulfidis, Alexiou, \& Tsaliki, 2016). 
And of course this is not true, as economic policy, on every level of analysis, is always a byproduct of both the 'positive' and the 'normative' dimensions of Economics (Jelveh, Kogut, \& Naidu, 2015; Pelikán \& Wegner, 2003)². In reality, the agents of economic policy, no matter how much they refer to their 'objective view', always set specific objectives that occur from their normative judgments and incorporate their ideological and political preferences and priorities. This way, economic policy is always a complex and difficultly divisible mixture of both 'normative' and 'positive' constituents:

- On the one hand, there is the part of economic policy that refers to the economic-quantitative mapping of the objectives, to the predictions of their effects and to their measurements; the 'positive' economics.

- On the other, there is the part of economic policy that refers to what are the desired objectives, targets and means of the policy; the 'normative' economics.

\footnotetext{
${ }^{2}$ Specifically, as it is already known, economic theory is characterized as 'positive' when it investigates a situation approaching the 'is', the 'was' or the 'would be, if'; i.e., when it explores, discovers and describes the relation among certain economic phenomena and figures, a relation that can be checked empirically. This, we can say it is the 'technical', the 'objective' part of it. On the contrary, economic theory is characterized as 'normative', when it approaches a situation under the light of 'ought to be' or 'what we ought to do'; i.e., in this part, the theory depends on and is affected by values and by the ideological beliefs on what is desirable and what is not. And, let us not forget, the differences regarding different moral propositions cannot be solved by considering solely the empirical data, as they are never a matter of 'pure data' but a matter of interpreting them.
} 
What always emerges in practice as an anti-crisis economic policy can only be a technical-ideological mixture, in the specific conditions posed by the dynamic evolution of the global system (Krishna, 1988; Nelson \& Sheffrin, 1991; Stilwell, 2011; Thompson $\&$ Hickson, 2001) (Figure 1).

Figure 1: Economic policy as a technical-ideological mixture

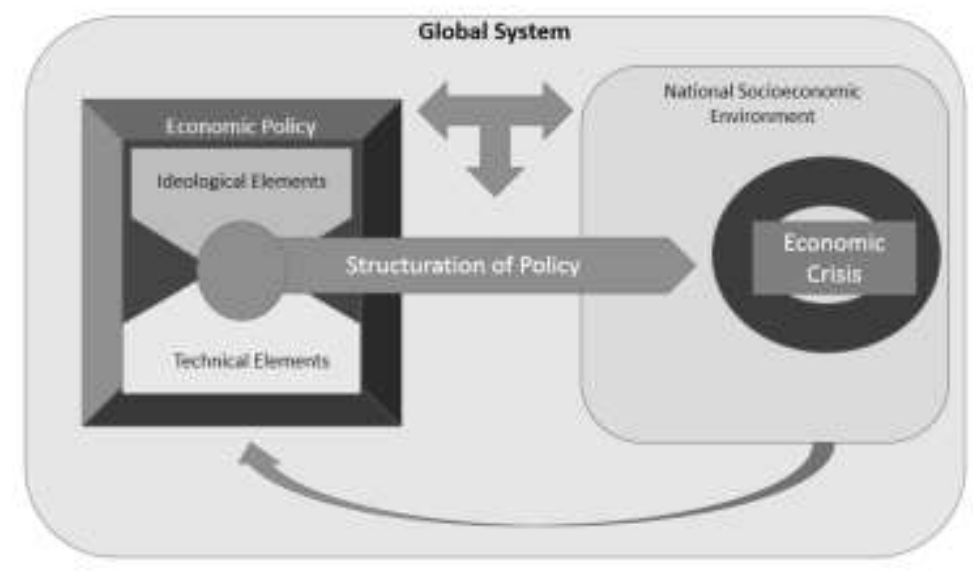

Therefore, the anti-crisis economic policy in Greece could only have an indivisible mixed technical-ideological character as well

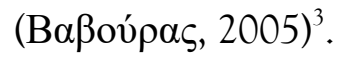

We believe, of course, that it is unsound and ineffective either the absolute 'positivizing' or the absolute 'normatizing' of any kind of

\footnotetext{
${ }^{3}$ The discrimination between positive and normative economics is useful regarding the origins of differences in matters of economic policy, even today. It is important to understand on what degree are the occurred differences a result of different normative judgments, thus of different evaluations on the objectives or the means to be adopted, or a result of different evaluations on the measurements or the effects of the objectives or of the means of the economic policy.
} 
294 economic policy ${ }^{4}$. On the contrary, we must accept the constantly 'mixed character' of economic policy, without, however, neglecting the individual components: technical and ideological. Economic policy must be perceived, without illusions, as a 'scientific' and a 'moral' entity at the same time; in other words, as we will see later on, as a 'strategic' view and action.

Meanwhile, the superficial approach to the understanding of the formulation of economic policy is very often based on the assumption that the basic aim of those that exercise it (as if they were a completely homogeneous group, something that of course can never happen) is the maximization of a given and indubitable social welfare function, within the limitations set by the structures of the related economic system. But, in reality, those who exercise economic policy usually avoid the strict determination of specific desired figures of the targets and means they possess (Simon, 1947).

Furthermore, those who exercise economic policy, more often, do not aim so much for the simultaneous achievement of all their targets, as they focus mostly on achieving only one (or a small number of similar and complementary targets) that are regarded as more important and of which the 'present figure' is considered unsatisfying. Then, they channel towards that target the greatest part of the available resources and means and right after, since this central

\footnotetext{
${ }^{4}$ And according to J.K. Galbraith (Galbraith, 1987) economics is not useful when it exists separated from politics. Separating economics from politics and political motives is something sterile.
} 
target has been achieved to a 'satisfying degree', they turn their attention and available means to the next targets of their political agenda.

In this way, the general aims of economic policy, regarding also the structuration of anti-crisis policy, can only be characterized by their mixed - technical and ideological - content:

- They concern the 'generally desirable' economic and social directions, towards which the specific followed governmental policy is each time oriented.

- They incorporate, in a direct or indirect way, the central ideological as well as the managerial priorities followed by the government.

- They have, to a certain degree and according to each case, a totalizing and visionary content and they are not initially expressed in specific quantitative terms.

- They are based on and make use of, to a degree, the data provided by empirical reality and they use, also to a degree, methods of their scientific analysis.

- They express, directly or indirectly, the moral status quo of society and of the 'dominant pole' of the political system as well as the ideological directions of political elites.

- They compose the economic and social variables, thus creating the welfare function which the - always specific in space and time - economic policy tries to maximize. 
296 In practice, the above assertions remain unclear and incomprehensible for the Greek public opinion and for many agents that express and exercise politics in Greece. Specifically, we do not cease to detect the spread of various simplistic illusions. To be effective, the structuration of anti-crisis economic policy should be neither 'de-politicized' 5 nor 'de-technicalized' ${ }^{6}$; and these are conceptual misunderstandings that go on and keep spreading by various media that shape the public opinion, and with particularly negative political effects in the case of Greek crisis (Alcidi \& Gros,

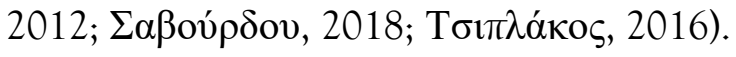

Economic policy as confrontational strategy in the context of the politico-economic cycle

As an immediate derivative of the previous relatively widespread misunderstandings, very often emerges the attempt of a conceptual 'de-strategizing' of economic policy, in the sense that some try to present it as potentially independent and autonomized from the specific structures and dynamics of the internal and external environment, inside of which the policy is structured, implemented and controlled (Monastiriotis \& Antoniades, 2009; Pappas, 2013; Triandafyllidou, 2009).

\footnotetext{
${ }^{5} \mathrm{~A}$ program of 'sheer' technocrats with the simultaneous halt of any kind of political claiming is never a case.

${ }^{6}$ On the direction of an extreme political voluntarism: The logic of 'people before the numbers'.
} 
On the contrary, we believe it must be understood that always the structuration of economic policy is the byproduct of a confrontational strategic process. It sets, directly or indirectly, a vision, it has objectives, it has agents and actors, it has an external environment, it has conflicting alternatives and it also has 'customers' - the citizens that validate it, or not, by voting.

In this interpretative perspective, after all, belongs also the classic model of the politico-economic cycle by B.S. Frey (Frey, 1978), which we consider to be very useful for perceiving the structuration of anti-crisis economic policy as a confrontational strategic process. The specific politico-economic model of analysis studies the mutual influence between the political and the economic sector of society, by focusing on the relation between the consumer-voter and the government. In particular, the basic concept of the model recognizes two factors of action, voters and government, and two cycles of action, economic and political. It is based, at the same time, on two distinguished mechanisms:

- The voters evaluate the performance of the government

- The government seeks ways to manage the economy in order to remain in power and to maximize its usefulness.

So, the influence of the economy on the political institutions is expressed by an evaluation function, while the influence of the state on the economic institutions by a politics function. By examining Frey's model, we distinguish four main structural elements: 
i. Voters: We consider them to be 'logical'; they take into account the government's past and the expected governmental performance in regard to the state of the economy. Of course, there are widely divergent views on how fast voters anticipate the government's performance based on its past and whether they 'remember'.

ii. Government: We consider it to act as a whole and rationally; it maximizes its usefulness by identifying its ideological targets and under limitations: ideological, managerial and economic.

iii. Political sector: Here we are mainly interested in parliamentary democracies and examine a two-way question; 'is the economy being led by the elections or the elections are determined by the course of the economy?'

iv. Economic sector: Many models cover a specific part of economy and mostly inflation and unemployment, but very few reflect the link between the evolution of the economy and the political process.

In this theoretical orientation we believe we can perceive with greater clarity the economic policy as a strategic-political process (Figure 2). 
Figure 2: The political process in the structuration of economic policy

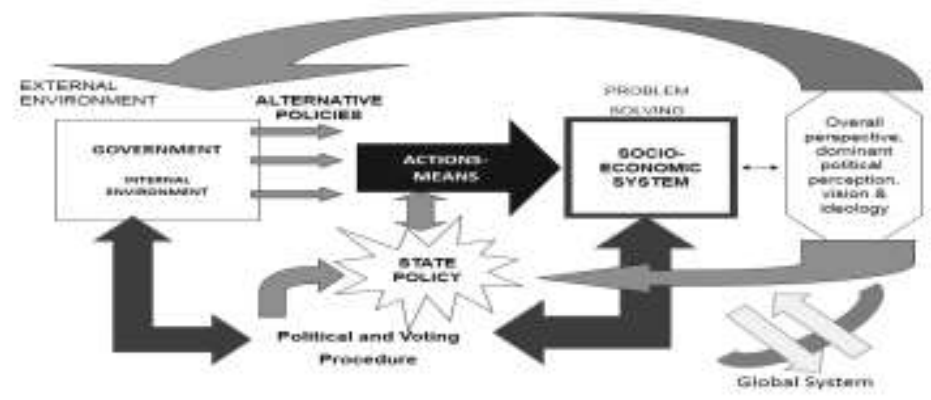

In this interpretative perspective it becomes easily clear that state policy in general - and, more specifically, economic policy as one of its main ingredients - is always a product of strategic procedures. And of course there is no 'objectively perfect' policy, regardless of its particular socioeconomic content, the specific space and time frame and its specific strategic aiming. Although it is the so called neutral aim of 'public interest' or 'common welfare' that is often presented as the basic goal of economic policy, we ought to understand that, always, every state/economic policy has its own, particular politico-confrontational content: thus, it is itself a strategic creation (Clausewitz, 1832; Kaplan \& Norton, 2004; Kim \& Mauborgne, 2015; Machiavelli, 1532).

In this way, the challenge for the structuration of economic policy becomes purely of strategic-political nature and can be simply put by the following question: "Which alternative policy shall I follow under the specific socio-political conditions and at what political 
300 benefits and costs?' And here, in the structuration of a systematic economic policy, the agent of planning and action ought to study the evolution of the related external environment (socioeconomic system) as well as the potential of the related internal environment (government-state system), by calculating the possible opportunities and threats - that are born by the change of the agent's overall external, national, international and global environment - and by trying to make use of the agent's comparative strong points and to protect the comparatively weak ones.

In this conceptual direction, we believe that an anti-crisis economic policy could be 'demystified' in the eyes of a big number of citizens and politicians in Greece today: The anti-crisis economic policy is not an 'axiom', it is not an 'all-weather' solution, it must be always a 'down to earth' strategy with clear boundaries, as an exercise of realism and dynamic balance.

Objectives, targets, kinds, means and time-lags in the structuration of economic policy

A third misconception on the anti-crisis economic policy regards the widespread wrong belief that economic policy can be supposedly produced and implemented 'automatically', without hierarchies and priorities, within an environment of no 'attritions' and delays (Edsall, 2012; Martins, 2011; Mehta, 2013).

Economic policy gets full meaning only as long as it manages to give specific answers to the 'what', 'how' and 'in what time frame' 
questions. Therefore, any ungradated and timeless perception of economic policy is deeply misleading.

In particular, in order to understand the meaning of economic policy, we must clarify primarily the specific concept of its objectives and targets. According to the traditional definition by E.S. Kirschen, the objectives of economic policy can be nothing but 'economic translations' of the general political aims into concepts that can be quantified (Kirschen, 1964). More specifically and also according to K.E. Boulding, an objective in economic policy is always one of the variables describing the economic system and it is considered an 'important' variable in the sense that the increase or decrease of its quantity defines whether the system will improve or get worsen (Boulding, 1958).

So, each objective of economic policy refers to a specific and measurable aim of the agents of economic policy and defines a quantitative criterion of the policy's success. An objective can contribute to the cover of more than one general aims of economic policy. On the other hand, targets are in particular the individual, quantified, timed, sectorally and geographically focused results to be achieved for the objective of economic policy to be covered (Figure 3). 
Figure 3: General aims, objectives and targets of Economic Policy

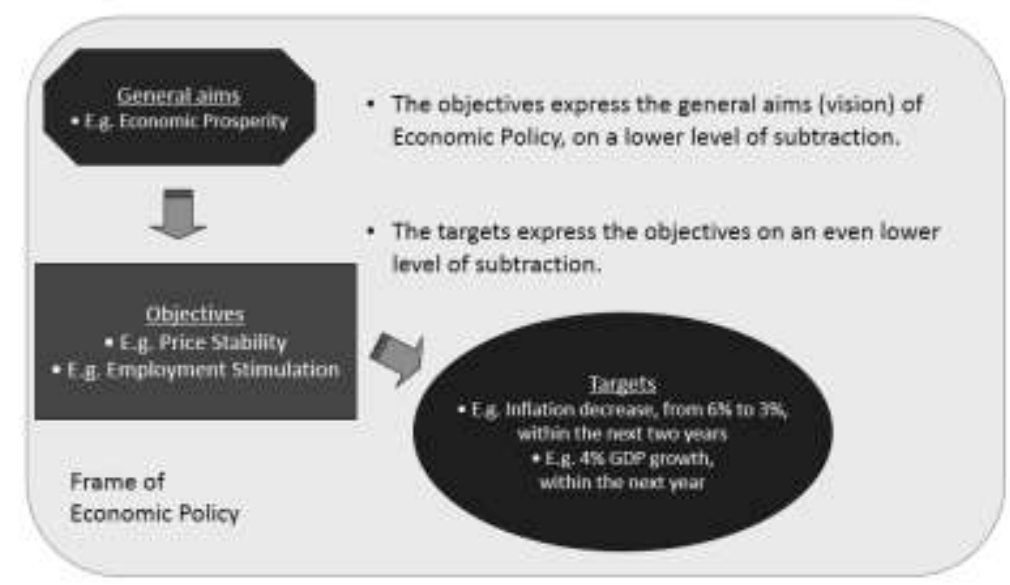

So, any confusion among the political vision, the objectives and the targets of the policy becomes particularly detrimental, on the degree that the agent who plans and exercises economic policy seeks more clarity in the underlying strategic plan. Also, we believe that there is a particularly clarifying distinction among the means of economic policy, on the basis of their nature. We can practically distinguish them in three basic kinds:

- Economic figures-quantities: Their changes, as independent variables, do not affect the structure and the bases of the economic system? .

\footnotetext{
${ }^{7}$ E.g.: Taxes, government expenditure, quantity of money, social security contributions, interest rates, fractional-reserve banking etc.
} 
- Institutions: These means have a qualitative character; they change some structural elements of the socioeconomic system, but without changing radically its basic structure and fundamental elements ${ }^{8}$.

- Reforms: These means lead to radical qualitative restructurings, affect drastically the structure of the socioeconomic system and influence its structural foundations and its basic developmental orientations, in the context of global dynamics (Bates \& Krueger, 1993; Bluhm, Crombrugghe, \& Szirmai, 2014; Bouis, Causa, Demmou, Duval, \& Zdzienicka, 2012; Drazen \& Grilli, 1993; Hill, 2013) $)^{9}$ (Figure 4).

Figure 4: Qualitative and quantitative measures in Economic Policy

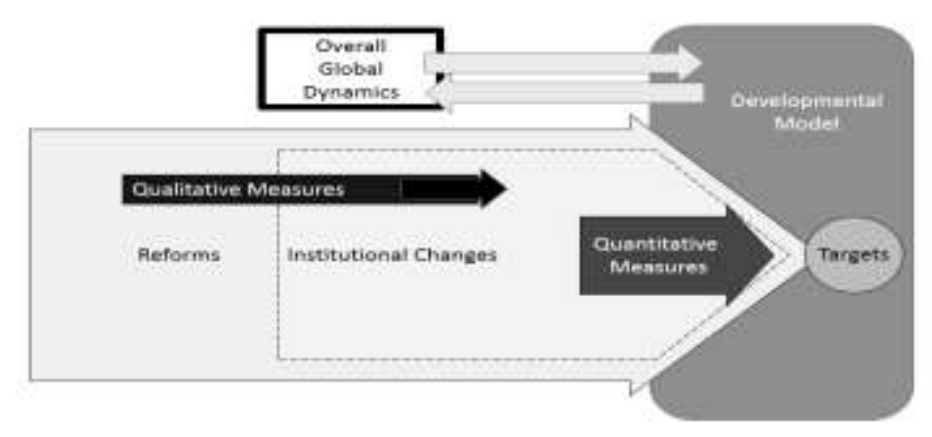

\footnotetext{
${ }^{8}$ E.g.: Regulations regarding occupational closure, conditions of employment, license granting, investments etc.

${ }^{9}$ E.g.: Deep structural changes of taxation, monetary system, social security, branches of economic activity etc.
} 
In this sense, under no circumstances should we maintain the wrong impression that all 'medicines' proposed by economic policy can have the same effect on the 'patient'-economic system and, consequently, under no circumstances should we expect from simple quantitative-conjunctural measures to redeploy the deeper developmental model of our socioeconomic system in qualitative terms; as unfortunately the Greek public opinion often seems to accept (Moschonas, 2016).

In particular, for the development of an effective economic policy, we ought to always understand the essential differences between a conjunctural and a structural economic policy (Clark, 1940; Kuczynski \& Williamson, 2003; Leon, 1967; Williamson, 2005).

- The conjunctural economic policy includes short-term targets relating to the current economic situation (conjuncture); it regards a short-term period, the present and near future.

- The structural economic policy is composed by longterm targets of politics; these targets regard the structural/institutional aims of economic policy and longterm periods, of at least ten years.

Of course, there must always be a clarification concerning the connection between conjunctural and structural economic policy. In practice, they are tightly connected, but they should not be confused with each other nor should the one substitute the other. The 
conjunctural, aiming for temporary conditions of stability, creates the basis needed for the successful exercising of structural policy. But conjunctural policy cannot secure on its own a long-term success of any economic policy, as several analysts continue to claim in the case of the Greek crisis. The corrective-structural modernization of a socioeconomic system can occur only through a consistent, cohesive and stable structural policy.

Furthermore, there should always be interest in the examination of time-lags (Alt \& Woolley, 1982; Golder, 2010; Masciandaro \& Suardi, 2014; Singh, 2010; Tepe \& Vanhuysse, 2010) characterizing every economic policy. Economic policy is of course never implemented in conditions of 'zero attrition' nor does it take place timelessly and automatically. On the contrary, it always faces time-lags and we can distinguish two particular kinds of these lags:

- Internal time-lag

- External time-lag.

Specifically, internal time-lag can be directly affected by the agents of policy, on the measure of their managerial abilities. This time-lag refers to the time elapsing between the moment the need for measures is perceived - in order for the gap between the actual and the desired figures and targets of the economic policy to be covered and the moment the agents of the policy take the allegedly necessary corrective measures. Internal time-lag is divided into: 
- Lag of recognition; i.e., the time required for the agents of policy to recognize the need for measures, which will correct the up to date policy.

- Lag of decision; i.e., the time required for necessary decisions regarding the corrective measures to be made by the agents of economic policy.

- Lag of management; i.e., the time required for decisions changing the currently implemented policy.

The external time-lag, on the contrary, cannot be directly affected by the agents of policy. This time-lag refers to the time elapsing between the moment of implementing the corrective measures and the moment they completely exhaust their effects on the figures of the targets of economic policy. External time-lag is usually divided into:

- Time-lag of influence on intermediate variables of policy $^{10}$.

- Time-lag of the final variables or targets of policy ${ }^{11}$.

Therefore, what is of great importance regarding the effectiveness of every economic policy is the effort of its agent, firstly, to reduce the internal time-lags that concern his own strategic implementation, by rearranging and enhancing his internal strategic

\footnotetext{
${ }^{10}$ E.g.: The time elapsing between a change in income tax rate and the influence on aggregate demand.

${ }^{11}$ E.g.: The time elapsing between a change in aggregate demand and the change in the level of aggregate employment, if we assume that the latter is the target of the implemented policy.
} 
and managerial forces, and, secondly, to predict relatively accurately the external lags in order to have no illusions regarding the time needed for his strategy to pay off. As far as Greece is concerned, dealing with time-lags is a 'traditional' weakness of the Greek economic policy-making.

Overall, we believe all these theoretical notes to be very important to the effort of 'demystifying' the anti-crisis economic policy needed for Greece, during the time when a large part of our fellow citizens and of those in power continue to seek some 'perfect' policies in measures that are fragmentary, occasional and 'spineless' and, in fact, to anticipate in vain the immediate implementation and

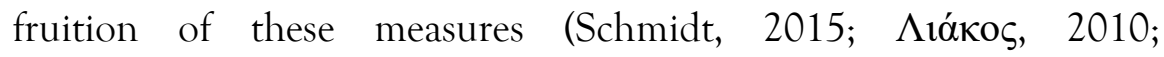

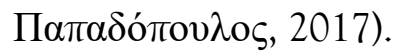

\section{CONCLUSION: BREAKING THE VICIOUS CIRCLE OF MISCONCEPTIONS}

To sum up our conclusions, we believe that an important factor of restraint regarding Greece's effort of overcoming the crisis is the constant activation of a 'vicious circle' of misunderstandings on the very concept of the anti-crisis economic policy; by a great part of both the citizens and the political leaders of the country. And each link on this circle prescribes the production and strengthening of the next circle in row, after having been produced and strengthened by the misunderstandings of the previous one (Figure 5). 
Figure 5: The vicious circle of the wrong perception of economic policy in conditions of crisis

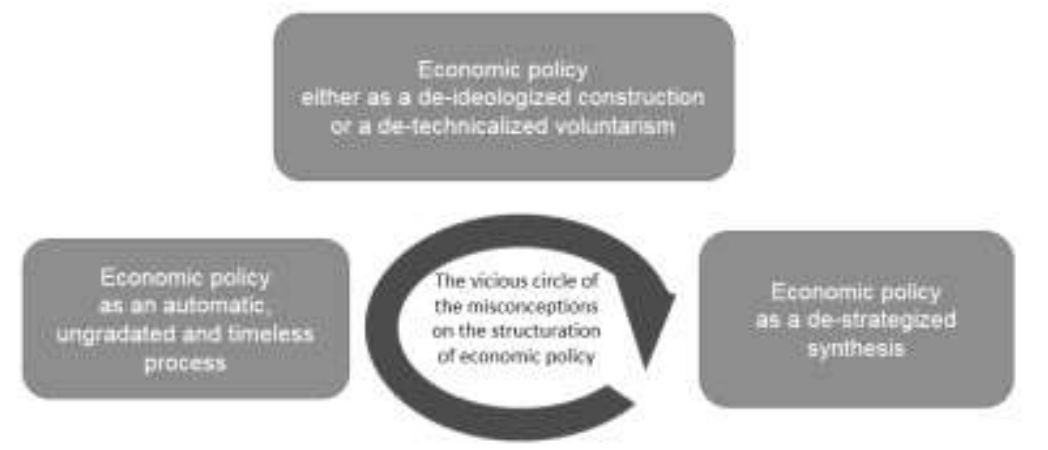

Specifically, in practice, the perception of economic policy either as a de-ideologized construction or as a figment of a supposedly completely de-technicalized voluntarism has fed and continues to feed political illusions; illusions of the type 'everything is numbers and have one single interpretation' or 'numbers are unnecessary and everything is a matter of decision'.

Next, the relevant perception of economic policy articulation as a de-strategized synthesis - supposedly autonomized and independent from the requirements and limits of the internal and external conditions - reproduces a spirit of imbalance that, through its lacking of realism, undermines any substantial effort towards creating and implementing a viable anti-crisis strategy.

Lastly, the erroneous perception of economic policy as a supposedly automatic, ungradated and timeless process does not cease to feed the illusions that seek the way out of the crisis in fragmentary, superficial and short-term measures 


\section{REFERENCES}

Abélès, M . (2008). Anthropologie de la globalisation. Paris: Payot.

Abraham-Frois, G. (2002). Dynamique économique (9e éd). Paris: Dalloz.

Acemoglu, D., Johnson, S., \& Robinson, J. (2004). Institutions as the Fundamental Cause of Long-Run Growth (Working Paper No. 10481). National Bureau of Economic Research. https://doi.org/10.3386/w 10481

Acemoglu, D., Johnson, S., \& Robinson, J. A. (2000). The Colonial Origins of Comparative Development: An Empirical Investigation (Working Paper No. 7771). National Bureau of Economic Research. https://doi.org/10.3386/w7771

Acemoglu, D., \& Robinson, J. A. (2009). Economic origins of dictatorship and democracy (1. paperback ed., reprint). Cambridge: Cambridge Univ. Press.

Acemoglu, D., \& Robinson, J. A. (2012). Why nations fail: the origins of power, prosperity, and poverty (1. ed). New York, NY: Crown Publ.

Adda, J. (2006). La mondialisation de l'économie: genèse et problèmes. Paris: La Découverte.

Aghion, P., Algan, Y., Cahuc, P., \& Shleifer, A. (2009). Regulation and Distrust (Working Paper No. 14648). National Bureau of Economic Research. https://doi.org/10.3386/w14648

Aglietta, M. (1997). Régulation et crises du capitalisme (Nouv. éd. rev. et corr., augm. d'une postface inéd). Paris: Odile Jacob.

Aglietta, M. (2010). La crise: le voies de sortie (Nouv. éd). Paris: M ichalon.

Alcidi, C., \& Gros, D. (2012). Why is the Greek economy collapsing? A simple tale of high multipliers and low exports. Brussels: Centre for European Policy Studies. Retrieved from https://www.ceps. eu/system/files/Greek\%20M ultipliers\%20and\%20Exp orts.pdf

Alesina, A., Favero, C., \& Giavazzi, F. (2012). The Output Effect of Fiscal Consolidations (Working Paper No. 18336). National Bureau of Economic Research. https://doi.org/10.3386/w18336

Alt, J. E., \& Woolley, J. T. (1982). Reaction Functions, Optimization, and Politics: Modelling the Political Economy of M acroeconomic Policy. American Journal of Political Science, 26(4), 709-740. https://doi.org/10.2307/2110969 
Amable, B. (2005). Les cinq capitalismes: diversité des systèmes économiques et sociaux dans la mondialisation. Paris: Seuil.

Amsden, A. (2001). The Rise of "The Rest." Oxford University Press. https://doi.org/10.1093/0195139690.001.0001

Ancel, J. (1936). Géopolitique. Paris: Delagrave.

Andreou, A., Andrikopoulos, A., \& Nastopoulos, C. (2017). Chapter 1 - Debt $M$ arkets, Financial Crises, and Public Finance in the Eurozone: Action, Structure, and Experience in Greece. In F. Economou, K. Gavriilidis, G. N. Gregoriou, \& V. Kallinterakis (Eds.), Handbook of Investors' Behavior During Financial Crises (pp. 3-28). Academic Press. https://doi.org/10.1016/B978-0-12-811252-6.00001-3

Asslund, A. (2011, November 18). The Failed Political Economy of the Euro Crisis. Retrieved September 18, 2018, from https://piie.com/blogs/realtime-economic-issues-watch/failed-politicaleconomy-euro-crisis

Bairoch, P., Saint-Girons, A., \& Asselain, J.-C. (2005). Mythes et paradoxes de I'histoire économique. Paris: La Découverte.

Balcerowicz, L. (1994). Transition to the M arket Economy: Poland, 1989-93 in Comparative Perspective. Economic Policy, 9(19), 72-97. https://doi.org/10.2307/1344601

Bates, R. H., \& Krueger, A. O. (Eds.). (1993). Political and economic interactions in economic policy reform: evidence from eight countries. Oxford, UK: Cambridge, Mass: Blackwell.

Baum, A., Checherita-Westphal, C., \& Rother, P. (2013). Debt and growth: New evidence for the euro area. Journal of International Money and Finance, 32, 809-821. https://doi.org/10.1016/j.jimonfin.2012.07.004

Beaujard, P., Berger, L., \& Norel, P. (Eds.). (2009). Histoire globale, mondialisations et capitalisme. Paris: Découverte.

Berger, S., \& Dore, R. (Eds.). (1996). National diversity and global capitalism. Ithaca, New York: Cornell University Press.

Bitzenis, A., Vlachos, V., \& Schneider, F. (2016). An Exploration of the Greek Shadow Economy: Can Its Transfer into the Official Economy Provide Economic Relief Amid the Crisis? Journal of Economic Issues, 50(1), 165-196. https://doi.org/10.1080/00213624.2016.1147918

Bluhm, R., Crombrugghe, D. de, \& Szirmai, A. (2014). Do weak institutions prolong crises?: On the identification, characteristics, and duration of declines during economic slumps. Munich: CESifo. 
Boissieu, C. de. (1980). Principes de politique économique (2e éd). Paris: Economica.

Boufounou, P., \& Avdi, K. (2016). Financial Crisis, Organizational Behavior and Organizational Silence in the Public Sector: A Case Study for Greece. SPOUDAI - Journal of Economics and Business, 66(1-2), 4678.

Bouis, R., Causa, O., Demmou, L., Duval, R., \& Zdzienicka, A. (2012). The Short-Term Effects of Structural Reforms: an Empirical Analysis (OECD Economics Department Working Papers, no. 949.). Paris: OECD Publishing.

Boulding, K. (1958). Principles of Economic policy. Ennglewood Clifs, NJ: Prentice-Hall.

Boyer, R. (1986). La théorie de la régulation: une analyse critique. Paris: La Découverte.

Boyer, R. (2015). Économie politique des capitalismes: théorie de la régulation et des crises. Paris: La Découverte.

Buiter, W., \& Rahbari, E. (2011). The future of the euro area: fiscal union, break-up or blundering towards a 'you break it you own it Europe.' Retrieved from http://faculty.london.edu/mjacobides/assets/documents/Citi_Euro_Futu re_Note_9.9.11.pdf

Buti, M., Turrini, A., \& Noord, P. van den. (2014, July 4). Reform and be reelected: Evidence from the post-crisis period. Retrieved August 27, 2018, from https://voxeu.org/article/reform-and-be-re-elected

Carfi', D., \& Schiliro', D. (2012). A framework of coopetitive games: Applications to the Greek crisis. AAPP Physical, Mathematical, and Natural Sciences, (1), A1-1-A1-32. https://doi.org/10.1478/AAPP.901A1

Carroll, W. K. (2010). The making of a transnational capitalist class: corporate power in the twenty-first century. London; New York: Zed.

Carroué, L. (2007). Géographie de la mondialisation (3e éd). Paris: A. Colin.

Chalikias, J. (2017). The Manufacturing Sector of Greece Before and During the Financial Crisis. International Journal of Economics \& Business Administration (IJEBA), $V(1), 3-17$.

Chang, H.-J. (2006). Understanding the Relationship between Institutions and Economic Development: Some Key Theoretical Issues (WIDER Working Paper Series No. DP2006/05). World Institute for Development Economic Research (UNU-WIDER). Retrieved from https://ideas.repec.org/p/unu/w paper/dp2006-05.html 
Chauprade, A. (2007). Géopolitique: constantes et changements dans I'histoire (3e éd. rev. et augm). Paris: Ellipses.

Chavagneux, C. (2016). Une brève histoire des crises financières: des tulipes aux subprimes. Paris: La Découverte.

Chevalier, J. M., \& Pastré, O. (Eds.). (2002). Où va l'économie mondiale? scénarios et mesures d'urgence. Paris: O. Jacob.

Cholezas, I., Kanellopoulos, N. C., M itrakos, T., \& Tsakloglou, P. (2013). The impact of the current crisis on private returns to education in Greece. Economic Bulletin, (38), 33-63.

Christodoulakis, N. (2010). Crisis, Threats and Ways Out for the Greek Economy. Cyprus Economic Policy Review, 4(1), 89-96.

Christopoulou, R., \& M onastiriotis, V. (2016). Public-private wage duality during the Greek crisis. Oxford Economic Papers, 68(1), 174-196. https://doi.org/10.1093/oep/gpv054

Clark, C. (1940). The conditions of economic progress. London: M acmillan and Co.

Clausewitz, C. von. (1832). On War.

Cohen, D. (2004). La mondialisation et ses ennemis. Paris: Grasset.

Colic-Peisker, V. (2010). Free floating in the cosmopolis? Exploring the identity-belonging of transnational knowledge workers. Global Networks, 10(4), 467-488. https://doi.org/10.1111/j.14710374.2010.00298.x

Crouch, C. (2005). Capitalist diversity and change: recombinant governance and institutional entrepreneurs. Oxford ; New York: Oxford University Press.

Cuche, D. (2013). La notion de culture dans les sciences sociales. Paris: La Découverte.

Dockès, P., \& Rosier, B. (1983). Rythmes économiques: crises et changement social: une perspective historique. Paris: La Découverte/M aspero.

Dockès, P., \& Rosier, B. (Eds.). (2002). Ordre et désordres dans l'économiemonde: ouvrage réalisé en hommage à Bernard Rosier. Paris: Presses universitaires de France.

Drazen, A., \& Grilli, V. (1993). The Benefit of Crises for Economic Reforms. The American Economic Review, 83(3), 598-607.

Dufoix, S. (2011). La dispersion: une histoire des usages du mot diaspora. Paris: Amsterdam. 
Edsall, T. B. (2012). The age of austerity: how scarcity will remake American politics (1st ed). New York: Doubleday.

Eichengreen, B., \& Panizza, U. (2014, July 30). Can large primary surpluses solve Europe's debt problem? Retrieved September 18, 2018, from https://voxeu.org/article/can-large-primary-surpluses-solve-europe-sdebt-problem

European Commission. (2010). The Economic Adjustment Programme for Greece (No. Occasional Papers 61) (p. 93). Retrieved from http://ec.europa.eu/economy_finance/publications/occasional_paper/2 010/pdf/ocp61_en.pdf

Featherstone, K. (2011). The JCM S Annual Lecture: The Greek Sovereign Debt Crisis and EMU: A Failing State in a Skewed Regime. JCMS: Journal of Common Market Studies, 49(2), 193-217. https://doi.org/10.1111/j.1468-5965.2010.02139.x

Frey, B. S. (1978). Politico-economic models and cycles. Journal of Public Economics, 9(2), 203-220. https://doi.org/10.1016/00472727(78)90043-9

Galbraith, J. K. (1987). Economics in perspective: a critical history. Boston: Houghton Mifflin.

Georgievski, B., \& M ostert, J. (2016). The prevalence of Suicidality during the economic crisis in Portugal, Italy, Ireland, Greece and Spain. In Proceedings of the 25th International Academic Conference, OECD Headquarters, Paris. International Institute of Social and Economic Sciences. https://doi.org/10.20472//AC.2016.025.025

Giannitsis, T., \& Zografakis, S. (2015). Greece: Solidarity And Adjustment In Times Of Crisis (IMK Studies No. 38-2015). IMK at the Hans Boeckler Foundation, Macroeconomic Policy Institute. Retrieved from https://ideas.repec.org/p/imk/studie/38-2015.html

Giddens, A. (1990). The Consequences of Modernity. Stanford, CA: Stanford University Press.

Gkintidis, D. (2018). European Funds and the Hermeneutics of the Capitalist Crisis: Insights from within the Greek State. PoLAR: Political and Legal Anthropology Review, 41(1), 142-159.

https://doi.org/10.1111/plar.12245

Glynos, J., \& Voutyras, S. (2016). Ideology as blocked mourning: Greek national identity in times of economic crisis and austerity. Journal of Political Ideologies, 21(3), 201-224. https://doi.org/10.1080/13569317.2016.1207300 
Golder, S. N. (2010). Bargaining Delays in the Government Formation Process. Comparative Political Studies, 43(1), 3-32. https://doi.org/10.1177/0010414009341714

Gorz, A. (2003). L'immatériel: connaissance, valeur et capital. Paris: Galilée.

Greenspan, A. (2008). The age of turbulence: adventures in a new world. London: Penguin.

Grove, A. S. (1999). Only the paranoid survive! how to exploit the crisis points that challenge every company. New York Toronto: Currency Doubleday.

Haliassos, M. (2015, June 20). Greece: Are we missing the reform opportunity of the crisis? Retrieved August 27, 2018, from https://voxeu.org/article/greece-seizing-crisis-s-reform-opportunities

Hannerz, U. (1992). Cultural complexity: studies in the social organization of meaning. New York, NY: Columbia Univ. Press.

Hardouvelis, G. A., \& Gkionis, I. (2016). A Decade Long Economic Crisis: Cyprus versus Greece. Cyprus Economic Policy Review, 10(2), 3-40.

Heilbron, J., Guilhot, N., \& Jeanpierre, L. (2009). Vers une histoire transnationale des sciences sociales. Sociétés contemporaines, 73(1), 121. https://doi.org/10.3917/soco.073.0121

Hill, H. (2013). The Political Economy of Policy Reform: Insights from Southeast Asia. Asian Development Review, 30(1), 108-130. https://doi.org/10.1162/ADEV_a_00005

Hughes, K. (2011). European Politics and the Euro Crisis: Ten Failures. Brussels: Friends of Europe, Policy Paper.

Huntington, S. P. (2017). Le choc des civilisations. Paris: O. Jacob.

International M onetary Fund. European Dept. (2017). Greece: Ex-Post Evaluation of Exceptional Access Under the 2012 Extended Arrangement-Press Release; Staff Report; and Statement by the Executive Director for Greece (Country Report No. 17/44) (p. 76). International M onetary Fund.

Ioannides, Y. M ., \& Pissarides, C. A. (2015). Is the Greek Crisis One of Supply or Demand? Brookings Papers on Economic Activity, 2015(2), 349373. https://doi.org/10.1353/eca.2015.0004

Jelveh, Z., Kogut, B., \& Naidu, S. (2015). Political Language in Economics (SSRN Scholarly Paper No. ID 2535453). Rochester, NY: Social Science Research Network. Retrieved from https://papers.ssrn.com/abstract $=2535453$ 
Juko, S. (2010). Have the media made the greek crisis worse? An inquiry into the credit crisis of the state. Economic Sociology the European Electronic Newsletter, 12(1), 28-41.

Kapitsinis, N. (2018). The impact of economic crisis on firm relocation: Greek SME movement to Bulgaria and its effects on business performance. GeoJournal, 1-23. https://doi.org/10.1007/s10708-018-9863-6

Kaplan, R. S., \& Norton, D. P. (2004). Strategy maps: converting intangible assets into tangible outcomes. Boston: Harvard Business School Press.

Katsimi, M ., \& Moutos, T. (2010). EMU and the Greek crisis: The politicaleconomy perspective. European Journal of Political Economy, 26(4), 568-576. https://doi.org/10.1016/j.ejpoleco.2010.08.002

Kazemi, H., \& Sohrabji, N. (2012). Contagion in Europe: Examining the PIIGS Crisis. International Advances in Economic Research, 18(4), 455-456. https://doi.org/10.1007/s11294-012-9366-z

Keck, F. (2010). Un monde grippé. Paris: Flammarion.

Kentikelenis, A. E. (2018). The social aftermath of economic disaster: Karl Polanyi, countermovements in action, and the Greek crisis. SocioEconomic Review, 16(1), 39-59. https://doi.org/10.1093/ser/mwx031

Kim, W. C., \& Mauborgne, R. (2015). Blue ocean strategy: how to create uncontested market space and make the competition irrelevant (Expanded edition). Boston, Massachusetts: Harvard Business Review Press.

King, D., \& Le Galès, P. (2011). Sociologie de l'État en recomposition. Revue française de sociologie, 52(3), 453. https://doi.org/10.3917/rfs.523.0453

Kirschen, E. S. (1964). Economic policy in our time. Amsterdam: NorthHolland.

Kleinknecht, A. (1986). Long waves, depression and innovation. De Economist, 134(1), 84-108. https://doi.org/10.1007/BF01705903

Koch, O., \& Mattelart, T. (Eds.). (2016). Géopolitique des télévisions transnationales d'information. Paris: Mare \& Martin.

Koniordos, S. (2011). Living on Borrowed Money: On the Social Context and Response of the Current Greek Crisis. Economic Sociology, 12(3), 11.

Kotler, P., \& Caslione, J. A. (2009). Chaotics: the business of managing and marketing in the age of turbulence (1st ed). New York: American Management Association. 
Kouretas, G., \& Vlamis, P. (2010). The Greek crisis: Causes and implications. Panoeconomicus, 57(4), 391-404. https://doi.org/10.2298/PAN1004391K

Koutsoukis, N.-S., \& Roukanas, S. (2011). The Greek crisis that should have been avoided. Scientific Bulletin - Economic Sciences, 10(1), 21-27.

Krishna, R. (1988). Ideology and Economic Policy. Indian Economic Review, 23(1), 1-26.

Krugman, P. (1992). Toward a Counter-Counterrevolution in Development Theory. The World Bank Economic Review, 6(suppl 1), 15-38. https://doi.org/10.1093/wber/6.suppl_1.15

Kuczynski, P.-P., \& Williamson, J. (2003). After the Washington consensus: restarting growth and reform in Latin America. Washington, D.C.: Institute for international economics.

Kuforiji, J. O. (2016). Greece Financial Crisis: The Genesis, Implications, and Policy Options. Journal of Applied Financial Research, 1, 55-74.

Lacoste, Y. (2006). Géopolitique: la longue histoire d'aujourd'hui. Paris: Larousse.

Lacoste, Y. (2014). La géographie, ça sert, d'abord, à faire la guerre (Éd. augm). Paris: Éd. La Découverte.

Laudicina, P. A., \& Peterson, E. R. (2016). From Globalization to Islandization (Global Business Policy Council (GBPC) /Research Report) (p. 26). ATKearney. Retrieved from https://www.atkearney.com/web/globalbusiness-policy-council/article?/a/from-globalization-to-islandization

Leon, P. (1967). Structural change and growth in capitalism: a set of hypotheses. Baltimore: Johns Hopkins Press.

Lévy, J. (Ed.). (2008). L'invention du monde: une géographie de la mondialisation. Paris: Presses de la Fondation nationale des sciences politiques.

Lorenzi, J. H., Pastré, O., \& Toledano, J. (1980). La crise du XXe siècle. Paris: Économica.

Luttwak, E. N. (1990). From Geopolitics to Geo-Economics: Logic of Conflict, Grammar of Commerce. The National Interest, (20), 17-23.

Machiavelli, N. (1532). The Prince.

Magoulios, G., \& Chouliaras, V. (2014). The Repercussions of the Financial Crisis (2008) on the Foreign Trade Between Greece and the Balkan Countries (BCs). In A. Karasavvoglou \& P. Polychronidou (Eds.), Economic Crisis in Europe and the Balkans (pp. 51-64). Heidelberg: 
Springer International Publishing. https://doi.org/10.1007/978-3-31900494-5_4

Manasse, P. (2015, June 12). What went wrong in Greece and how to fix it: Lessons for Europe from the Greek crisis. Retrieved August 27, 2018, from https://voxeu.org/article/what-went-w rong-greece-and-how-fix-it

Mandel, E. (1995). Long waves of capitalist development: a Marxist interpretation: based on the Marshall lectures given at the University of Cambridge (2nd rev. ed). London; New York: Verso.

Marangos, J. (Ed.). (2017). The Internal Impact and External Influence of the Greek Financial Crisis. Cham: Springer International Publishing. https://doi.org/10.1007/978-3-319-60201-1

Martel, F. (2010). Mainstream: enquête sur cette culture qui plaît à tout le monde. Paris: Flammarion.

Martins, N. (2011). The Revival of Classical Political Economy and the Cambridge Tradition: From Scarcity Theory to Surplus Theory. Review of Political Economy, 23(1), 111-131.

https://doi.org/10.1080/09538259.2010.510319

Masciandaro, D., \& Suardi, M . (2014). Delays and Distorsions in Reforming Banking Regulation: A Political Economy Tale. SSRN Electronic Journal. https://doi.org/10.2139/ssrn.2488452

Matsaganis, M. (2013). The Greek crisis: social impact and policy responses. Berlin: Friedrich-Ebert-Stiftung, Department of Western Europe/North America.

Mattelart, A. (2009). Histoire de la société de l'information (4. éd). Paris: La Découverte.

Mattelart, A., \& Neveu, É. (2010). Introduction aux Cultural Studies. Paris: La Découverte.

Mavroudeas, S. (2014). Greek Capitalism in Crisis: Marxist Analyses. London and New York: Routledge.

Mavroudeas, S. D. (2016). The Greek crisis: structural or conjunctural? In T. Subasat, The Great Financial Meltdown (pp. 307-327). Edward Elgar Publishing. https://doi.org/10.4337/9781784716493.00028

Mehta, L. (2013). The Limits to Scarcity: Contesting the Politics of Allocation. London: Routledge. https://doi.org/10.4324/9781849775465

Michalet, C. A. (1985). Le capitalisme mondial. Paris: Presses universitaires de France. 
M itsakis, F. V. (2014). The Impact of Economic Crisis in Greece: Key Facts and an Overview of the Banking Sector. Business and Economic Research, 4(1), 250. https://doi.org/10.5296/ber.v4i1.5515

M itsopoulos, M., \& Pelagidis, T. (2009). Vikings in Greece: Kleptocratic Interest Groups in a Closed, Rent-Seeking Economy. The Cato Journal, 29(3), 399.

Monastiriotis, V., \& Antoniades, A. (2009). Reform that! Greece's failing reform technology: beyond 'vested interests' and 'political exchange' (Hellenic Observatory Papers on Greece and Southeast Europe No. GreeSE Paper No 28 GreeSE Paper No 28) (p. 40).

Moore, W. E. (1966). Global Sociology: The World as a Singular System. American Journal of Sociology, 71(5), 475-482.

M oschonas, G. (2016, February). What Greeks Believe. Retrieved September 20, 2018, from https://www.dianeosis.org/en/2016/02/what-dogreeks-believe/

Mourmouras, A., Ivanova, A., Anayotos, G., \& Mayer, W. (2003). What Determines the Implementation of IMF-Supported Programs? (No. Working Paper No. 03/8). International Monetary Fund.

Naisbitt, J. (2006). Mind set! reset your thinking and see the future (1st ed). New York: Collins.

Naisbitt, J., \& Naisbitt, D. (2010). China's megatrends: the 8 pillars of a new society (1st ed). New York, NY: Harper Business.

National Intelligence Council (U.S.). (2008). Global trends 2025: a transformed world. New York: Cosimo Reports.

Nelson, J. A., \& Sheffrin, S. M. (1991). Economic Literacy or Economic Ideology? Journal of Economic Perspectives, 5(3), 157-165. https://doi.org/10.1257/jep.5.3.157

Noiriel, G. (2007). À quoi sert "l'identité nationale." Marseille: Agone.

North, D. (2005). Le processus du développement économique. Paris: Éditions d'Organisation.

North, D. C. (1990). Institutions, institutional change, and economic performance. Cambridge; New York: Cambridge University Press.

Pappas, T. S. (2013). Why Greece Failed. Journal of Democracy, 24(2), 3145. https://doi.org/10.1353/jod.2013.0035

Pelikán, P., \& Wegner, G. (Eds.). (2003). The evolutionary analysis of economic policy. Cheltenham: Elgar. 
Perez, C. (2010). Technological revolutions and techno-economic paradigms. Cambridge Journal of Economics, 34(1), 185-202. https://doi.org/10.1093/cje/bep051

Perroux, F. (1962). L'économie des jeunes nations. Industrialisation et groupements de nations. Paris: Presses Universitaires de France - PUF.

Petmesidou, M., \& Polyzoidis, P. (2015). What Policy Innovation For Youth in the Era of Prolonged Austerity? The Case of Greece. Cyprus Economic Policy Review, 9(2), 35-77.

Pitelis, C. N. (2012). On PIIGs, GAFFs, And BRICs: An Insider-Outsider's Perspective on Structural and Institutional Foundations of the Greek Crisis. Contributions to Political Economy, 31(1), 77-89. https://doi.org/10.1093/cpe/bzs002

Rapanos, V. T., \& Kaplanoglou, G. (2014). Governance, Growth and the Recent Economic Crisis: The Case of Greece and Cyprus. Cyprus Economic Policy Review, 8(1), 3-34.

Ray, D. (1998). Development economics. Princeton, N.J: Princeton University Press.

Robertson, R. (1992). Globalization: Social theory and global culture. London and Thousand Oaks and New Delhi: Sage.

Rodrik, D. (2011). The globalization paradox: why global markets, states, and democracy can't coexist. Oxford ; New York: Oxford University Press.

Rosier, B. (1985). Croissance et crise capitalistes (2e éd. ent. ref). Paris: Presses Universitaires de France - PUF.

Salmon, J. M. (2000). Un monde à grande vitesse: globalisation, mode d'emploi. Paris: Seuil.

Sapir, J. (2011). La démondialisation. Paris: Seuil.

Schmidt, V. A. (2015). Changing the policies, politics, and processes of the Eurozone in crisis: will this time be different? Social Policy in the European Union: State of Play, 33.

Schumpeter, J. (1939). Business cycles: a theoretical, historical, and statistical analysis of the capitalist process. New York: McGraw-Hill.

Simon, H. A. (1947). Administrative behavior. New York: Macmillan Publishers.

Singh, R. (2010). Delays and Cost Overruns in Infrastructure Projects: Extent, Causes and Remedies. Economic and Political Weekly, 45(21), 43-54. 
Skalkos, D. P. (2018). Studying the political economy of reforms: The Greek case, 2010-2017. Theoretical and Applied Economics, XXV2(615), Summer), 163-186.

Stilwell, F. (2011). Political Economy: The Contest of Economic Ideas (Third Edition). Oxford, New York: Oxford University Press.

St-Onge, J.-C. (2000). L'imposture néolibérale. Marché, liberté et justice sociale. Montréal, Québec: Écosociété.

Strange, S. (1996). The retreat of the state: The diffusion of power in the world economy. Cambridge: Cambridge University Press. https://doi.org/10.1017/CB09780511559143

Tepe, M., \& Vanhuysse, P. (2010). Who Cuts Back and When? The Politics of Delays in Social Expenditure Cutbacks, 1980-2005. West European Politics, 33(6), 1214-1240. https://doi.org/10.1080/01402382.2010.508903

Terzi, A. (2015). Reform momentum and its impact on Greek growth (Research Report No. 2015/12). Bruegel Policy Contribution. Retrieved from https://www.econstor.eu/handle/10419/126685

Thompson, E. A., \& Hickson, C. R. (2001). Ideology and the Evolution of Vital Institutions: Guilds, The Gold Standard, and Modern International Cooperation ( $2 \mathrm{nd}$ ed.). Springer US. Retrieved from //www.springer.com/gp/book/9780792373902

Tinbergen, J. (1956). Economic Policy: Principles and Design. North-Holland Publishing.

Triandafyllidou, A. (2009). Greek Immigration Policy at the Turn of the 21st Century. Lack of Political Will or Purposeful M ismanagement? European Journal of Migration and Law, 11(2), 159-177. https://doi.org/10.1163/157181609X440013

Triantopoulos, C., \& Staikouras, C. (2017). SOEs in Greece: structural reforms, economic crisis and financial constraints. International Journal of Public Policy, 13(6), 358. https://doi.org/10.1504/IJPP.2017.087884

Tsoulfidis, L., Alexiou, C., \& Tsaliki, P. (2016). The Greek economic crisis: causes and alternative policies. Review of Political Economy, 28(3), 380-396. https://doi.org/10.1080/09538259.2016.1163819

Veltz, P. (2008). Le nouveau monde industriel. Paris: Gallimard.

Vlados, C., Deniozos, N., \& Chatzinikolaou, D. (2018a). Global Crisis, Innovation and Change Management: Towards a New Systemic Perception of the Current Globalization Restructuring. International Business Research, 11(8), 9-29. https://doi.org/10.5539/ibr.v11n8p9 
Vlados, C., Deniozos, N., \& Chatzinikolaou, D. (2018b). The "Evil Globalization" \& the Central Dialectic Tug-of-War in the New Globalization's Shaping. Civitas Gentium, 6(1), 89-134.

Vlados, C., Deniozos, N., Chatzinikolaou, D., \& Demertzis, M. (2018). Perceiving Competitiveness under the Restructuring Process of Globalization. International Journal of Business and Management, 13(8), 135-153. https://doi.org/10.5539/ijbm.v13n8p135

Williamson, J. (2005). The Washington consensus as policy prescription for development. Development challenges in the 1990s: leading policymakers speak from experience, 31 .

Williamson, O. E. (2000). The New Institutional Economics: Taking Stock, Looking Ahead. Journal of Economic Literature, 38(3), 595-613.

Zettelmeyer, J., Trebesch, C., \& Gulati, M. (2013). The Greek debt restructuring: an autopsy. Economic Policy, 28(75), 513-563. https://doi.org/10.1111/1468-0327.12014

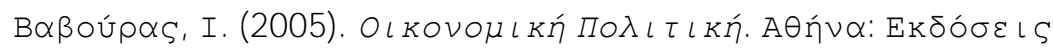
$\Pi \alpha \Pi \alpha \zeta \bar{\sigma}$.

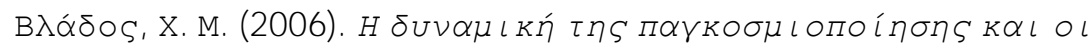

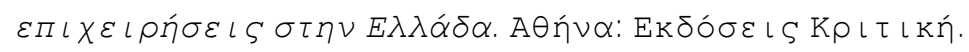

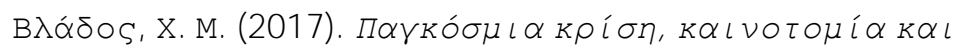

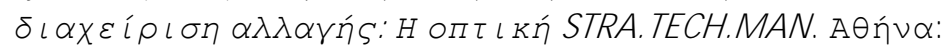

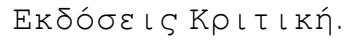

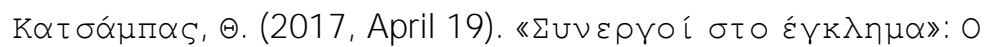

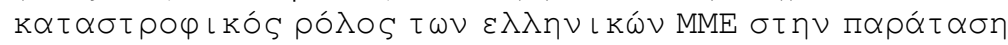

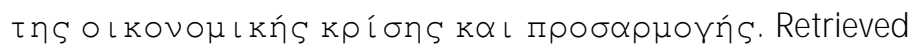
September 18, 2018, from http://www.huffingtonpost.gr/thanos_catsambas/_11209_b_16077316.html

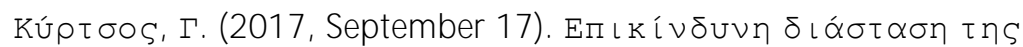

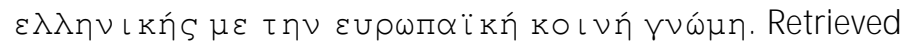
September 18, 2018, from https://freesunday.gr/apopseis/item/13255epikindynh-diastash-ths-ellhnikhs-me-thn-eyrw paikh-koinh-gnw mh

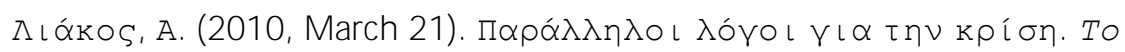
$B \eta ́ \mu \alpha$ Online. Retrieved from http://www .tovima.gr/2010/03/21/opinions/paralliloi-logoi-gia-tin-krisi/

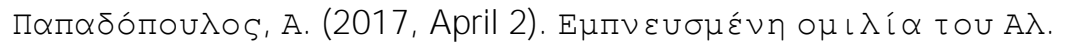

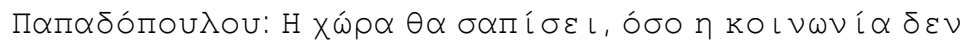

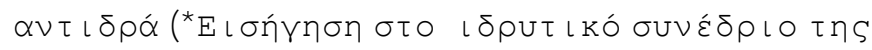

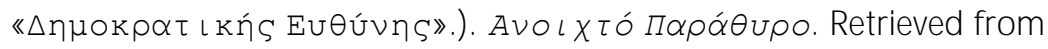




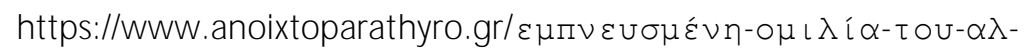
папфбо́поч/

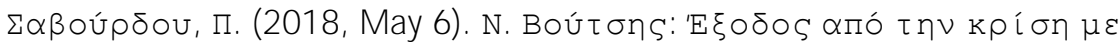

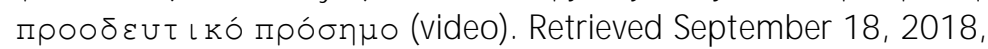
from http://www .ert.gr/eidiseis/ellada/politiki/voytsis-kathari-exodos/

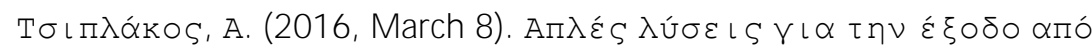

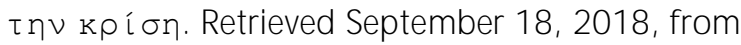
https://aristidistsiplakos.gr/49/

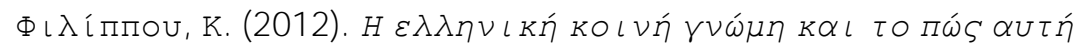

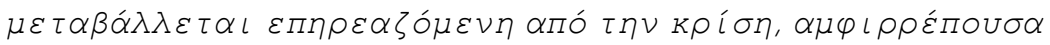

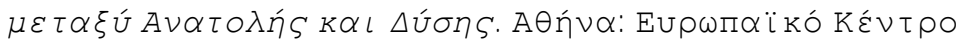

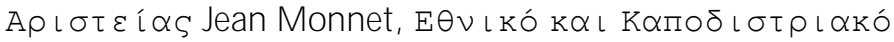

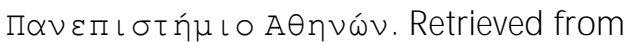
http://www.jmc.uoa.gr/fileadmin/jmc.pspa.uoa.gr/uploads/PDFs/l_Ellini ki_koini_gnomi___Kostas_V.FILIPPOU.pdf 